International Journal of Instruction e-ISSN: 1308-1470 • www.e-iji.net
October $2020 \bullet$ Vol.13, No.4

p-ISSN: 1694-609X

pp. $215-230$

Received: $27 / 10 / 2019$

Revision: 03/04/2020

Accepted: $22 / 04 / 2020$

OnlineFirst:11/07/2020

\title{
How Do Italian Teacher Trainees Conceive Assessment?
}

\author{
Serafina Pastore \\ Dr., University of Bari A. Moro, Italy, serafina.pastore@uniba.it
}

Nowadays, educational research points how teaching-learning quality is interwoven with teachers' conceptions of teaching, learning, curriculum, and assessment. Given this assumption, the present papers reports a study aimed to analyse teacher trainees' conceptions of assessment. On the backdrop of review of main international studies on teachers' assessment conceptions, this paper focuses on the Italian teacher trainees' conceptions of assessment. Data from 409 teacher trainees on Conceptions Of Assessment (COA) inventory were analysed in a MANOVA design. Differences and similarities between the current results and the COA model are highlighted: even though the Italian teacher trainees generally agreed with the assessment as a lever to improve teaching and learning, it is evident that they conceive assessment as misaligned from the accountability system. The implications of results for assessment education and training are also discussed.

Keywords: assessment, teachers' conceptions, teacher trainees, teacher education, educational research

\section{INTRODUCTION}

Political, socio-economic, and cultural changes, over the last twenty years, have led to a new «attention to the quality of education systems around the world and in particular to teacher quality» (Cochran-Smith, 2016: 96). If, on the one hand, teaching and teacher education have been recognized as a crucial elements that affect students' achievements and school improvement processes (Teddie \& Reynolds, 2000; Scheerens, 1992; Townsend \& Bates, 2007), on the other hand, educational research pointed the need to understand not only how teachers learn and develop professional competencies but also how design and implement formative paths really effective and responsive to teachers' learning needs (Darling-Hammond \& Bransford, 2005). Thus, it is important to consider the relationship between the teaching quality within an educational system and what conceptions teachers have of teaching itself, of learning, curriculum, and assessment (Brown, 2004). This last point represents a pivotal element for teacher education in terms of educational policy and practice. Prior research indicates that teachers' conceptions impact teaching actions and that teachers' conceptions influence also teachers' reactions to institutional and policy changes within an educational system.

Citation: Pastore, S. (2020). How Do Italian Teacher Trainees Conceive Assessment? International Journal of Instruction, 13(4), 215-230. https://doi.org/10.29333/iji.2020.13414a 
Therefore, exploring teachers' conceptions can be useful to understand what are implications and challenges for teacher education and teacher professional development. In this perspective, for example, the research focus on teacher trainees' conceptions is relevant in order to understand if, and how, teacher education programs influence their conceptions and their practices.

Given these assumptions, the present paper reports in the following a study aimed to analyse teacher trainees' conceptions of assessment in Italy. Moreover, this study intended to shift research attention on reasons why teachers' assessment practices are difficult to be changed (Daniel et al., 2014). Despite the implementation of several reforms in this school context over the last 15 years, and despite the long knowledge that teachers' conceptions influence the way they teach and the way they assess students, there has ben little research examining such opportunities and challenges for teacher education.

\section{BACKGROUND}

\section{Why Teachers' Conceptions Matter}

Conception is generally defined as all that a teacher thinks about the rationale of education and about the aim of teaching practice. Furthermore, conceptions, as cognitive structures, include beliefs, meanings, concepts, and preferences. However, there are also other elements to be considered such as personal, social, educational, and contextual background: all these aspects can impact teaching practice.

Conceptions work as a framework through which teachers can see, analyse, and interpret their action within a learning context (Calderhead, 1996; Marton, 1981). Conceptions can have a strong effect on how teachers teach and what students learn. Moreover, conceptions can influence teachers' reactions to institutional changes and policy innovation in the school system: the focus on teachers' conceptions, in this vein, is useful to understand what are the implications and the challenges for teacher education. As a consequence, within the teacher education field great attention has been deserved to teachers' conceptions.

\section{Prior Research on Teachers' Conceptions}

Different studies have tried to analyse teaching practice focusing on conceptions teachers have of:

- Learning (Entwistle, 1997; Marton \& Saljö, 1976);

- Teaching (Trigwell \& Prosser, 1997; Kember, 1997; Gow \& Kember, 1993; Pratt, 1992; Samuelowicz \& Bain, 1992);

- Curriculum (Cheung, 2000; Eisner \& Vallance, 1974);

- Self-efficacy (Tschannen-Moran et al., 1998; Guskey \& Passaro, 1994; Bandura, 1989); 
- Personal epistemology (Schraw et al., 2002; Wood \& Kardash, 2002; Schommer, 1990);

- $\quad$ Assessment (Brown, 2004; Stamp, 1987).

Some studies showed how teachers' conceptions influence what teachers teach and how they teach. Cheung and Wong (2002) pointed that teachers' conceptions about curriculum become particularly evident in assessment. Dahlin et al. (2001) proved how teachers' conceptions about assessment are generally polarized (e.g., summative and formative dimensions). Dwyer and Villegas (1993), instead, reported a more complex scenario for teachers' conceptions of assessment differentiated on four integrative domains: teaching for student learning; creating an environment for student learning; teacher professionalism, and the organization of content knowledge for student learning. Betoret and Artiga (2004) developed a four-way model of teachers' conceptions that is based on two different areas: the first teacher-centred versus student-centred, and the second one, process-centred versus product-centred.

Current studies are trying to understand if teachers' conceptions of assessment can be analysed in the life context of the classroom (Klenowski, 2016; Graham, 2005), how teachers develop these conceptions (Barnes et al., 2015; Fives \& Buehl, 2012), and what kind of factors influence them (Gebril \& Eid, 2017; Barnes et al., 2015; Kennedy, 2016; Daniel et al., 2014). While some studies unfold that variables such as numbers of years in education, numbers of years of professional experience, and socio-economic status do not affect teacher' conceptions of assessment, Vandeya and Killen (2007) pointed that teachers' conceptions can be affected by several factors like the education system, the subject matter, the teachers' beliefs in students' abilities, the perception of the community expectations. A very complex research object is now presenting, because conceptions about assessment are so complex, hierarchical, multidimensional, and interrelated (Brown, 2004).

The present study looks at teacher trainees' conceptions of assessment in the Italian school context. More specifically, participants in this study are students enrolled in a teacher education path for the secondary school grade (middle and high school). This one-year path is for graduate and post-graduate students with a different subject matter specialization (e.g., Maths, Physics, History, etc.) and with little experience in the school.

\section{The Study}

Given the importance teachers' conceptions have both for teaching practice and teacher education, the present study focuses on teacher trainees' conceptions of assessment. Due to the relevant changes in the Italian school system over the last 15 years (e.g. the implementation of the large-scale assessment program on the students' achievement in Italian and Math, or the implementation of the national school system evaluation) the analysis of teachers' conceptions of assessment represents an interesting element in order to design effective and responsive teacher education paths. While educational research and educational policy suggest the implementation of new assessment 
practices, in Italy, the resistances teachers have respect to institutional innovations represent an urgent problem in terms of the improvement of the national school system. The focus on teacher trainees' conceptions allows addressing the reasons why, despite institutional reforms and despite the implementation of new training education paths, teachers' assessment practices tend to be traditional, misaligned with national curriculum requirements, not responsive to accountability requirements, and not really effective. More specifically the focus on teacher trainees rather than on experienced teachers intends to shed light on conceptions teachers have before they enter definitively in the school system.

In order to analyse what conceptions the Italian teacher trainees have the Brown's model of teachers' conception on assessment has been used. This model $(2009 ; 2006 ; 2004)$ is the result of a large-scale research realized through the administration of Conceptions on Assessment inventory (COA). COA is made of 53 statements to which assign an agreement value ranging from 1 to 6 . The study was aimed to describe the four teachers' conceptions about assessment (Brown, 2004):

- Improvement. Often pointed as formative assessment or assessment for learning. Assessment is aimed to support teaching-learning process and to foster a meaningful and effective students' learning (24 items);

- School accountability. Assessment is functional to prove efficacy of teachers and students. Specific standards are required for this assessment and consequences are provided for those do not respect standards. There are two different aims: fostering educational quality and promoting school improvement (5 items);

- Student accountability. It is aimed to account students' learning through marks and performance criteria shared with families and other stakeholders (8 items);

- Irrelevant. This conception is related to the perception of external assessment as inappropriate, irrelevant, and inaccurate to pursue students' learning improvement. This trend becomes evident, for example, when external evaluations are considered to have negative effects on curriculum, on teachers, and even on students and teachers (13 items).

The main four conceptions include different factors and sub-factors (Fig. 1):

- Improvement, assessment is functional to improve teaching and students' learning; it supplies data and information for teachers' decision-making. This factor includes first-order factors: describe, student learning, teaching, and valid;

- School accountability, assessment allows to certify teachers' work and efficacy within the school system;

- Student accountability, assessment is functional to certify students' learning.

- Irrelevance, assessment is perceived as irrelevant or even dangerous for teachers' practice and students' learning. This factor includes the following dimensions: $\mathrm{bad}$, ignore and inaccurate. 


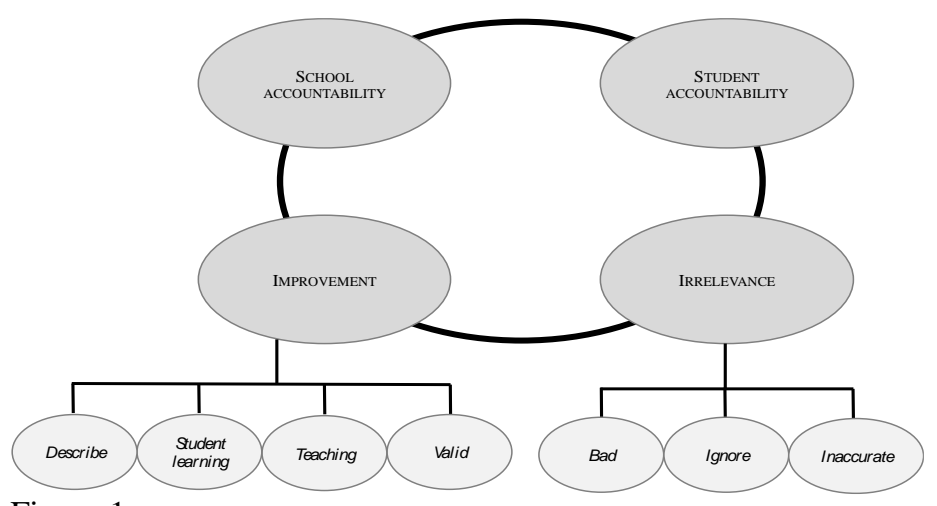

Figure 1

Conceptions of Assessment Model

Three versions of the inventory exist and several studies (Brown et al., 2019) have been realized in other countries such as in Queensland (Brown et al., 2011), USA (Calveric, 2010), Turkey (Vardar, 2010), Hong-Kong (Brown et al., 2009), and China (Li \& Hui, 2007). For this study the last version (COA_III) has been used.

\section{METHOD}

During the study a convenience sample of teacher trainees has been used. The COA_III questionnaire has been administrated to 417 teacher trainees at the end of Didactics modules of postgraduate certificate in two rounds of education courses. 409 valid questionnaires have been collected. Descriptive analyses (i.e. means, standard deviations, reliability estimates) were calculated to determine teacher trainees' conceptions of assessment. A Multivariate Analysis of Variance (MANOVA test) has been also performed to examine if socio-demographic variables (e.g. years of experience or school grade) impact the four main factors of the COA_III model (and the conceptions of assessment that teacher trainees have).

\section{FINDINGS}

Data analysis shows that respondents have an average age between 31 and 50 years. Remarkable is the gender bias: $82.6 \%$ of respondents are women. The $82.9 \%$ (N. 339) of teacher trainees have never attended educational or training courses on educational assessment and school evaluation; the $10.5 \%$ (N. 43) of them affirm that attended courses were about assessment and evaluation (Tab. 1). 
Table 1

Participants' Demographic Description

\begin{tabular}{ll}
\hline Variable & $\mathrm{N}$ \\
\hline Age & \\
$20-30$ & 4 \\
$31-40$ & 246 \\
$41-50$ & 142 \\
$51-60$ & 17 \\
Gender & \\
Male & 71 \\
Female & 338 \\
Teaching experience in years & \\
$0-1$ & 308 \\
$1-2$ & 96 \\
$2+$ & 5 \\
Educational paths or training courses on educational assessment & \\
Yes & 43 \\
No & 339 \\
Missing & 27 \\
\hline
\end{tabular}

Gathered data for this study are not sufficient to support a Confirmatory Factor Analysis (CFA). However, main components have been calculated and values for each conception have been compared. In the Table 2 are reported mean scores of factors, first-order factors, and values of index of reliability (Cronbach's $\alpha$ ). Alphas within the range of .39-.89 with an average value of .86 were good, indicating that the items had sufficiently robust reliabilities. The sub-dimensions valid within the Improvement firstorder factors is the only with a not good reliability. The teacher trainees of this study most frequently endorsed the Improvement conception of assessment $(\mathrm{M}=3.8, \mathrm{Sd}=.63)$ followed by Student Accountability $(\mathrm{M}=3.4 ; \mathrm{Sd}=.74)$, School Accountability $(\mathrm{M}=3.4$; $\mathrm{Sd}=.95)$ and gave least frequency to Irrelevance $(\mathrm{M}=3.2 ; \mathrm{Sd}=.51)$.

On the whole the Italian version of COA_III presents a good reliability and its items could be meaningfully used in further analysis.

Table 2

Mean Values and Factors Reliability

\begin{tabular}{lrrrr}
\hline Components & N. items & Mean & Sd & Cronbach $\alpha$ \\
\hline Improvement & 24 & 3.8 & .63 & .86 \\
Teaching & 6 & 4.4 & .78 & .79 \\
Learning & 7 & 3.8 & .80 & .84 \\
Describe & 6 & 3.4 & .72 & .69 \\
Valid & 5 & 3.3 & .54 & .39 \\
\hline Irrelevance & 13 & 3.2 & .51 & .81 \\
Bad & 5 & 2.4 & .78 & .67 \\
Ignore & 5 & 3.0 & .75 & .83 \\
Inaccurate & 3 & 3.8 & .95 & .61 \\
\hline School Accountability & 5 & 3.4 & .74 & .89 \\
\hline Student Accountability & 8 & 3.6 & .44 & .62 \\
\hline Total - COA_III & 50 & 3.5 & .86 \\
\hline
\end{tabular}


Teacher trainees involved in this study agree with Improvement conception of assessment: they consider assessment as functional to the improvement of teaching and learning processes (describe $=53.9 \%$; student learning $=63.6 \%$; teaching $=79.3$; valid $=$ $50.7 \%)$. Respondents don't consider assessment as Irrelevant. More specifically, if on the one hand, assessment is not considered as dangerous (ignore $=73.6 \%$; bad $=76.1 \%$ ), on the other hand, respondents consider their assessment practice as extremely inaccurate $(70.4 \%)$ : this last aspect is interesting to be considered on the backdrop of the growing demand for assessment literate teachers in the school. For School Accountability and Student Accountability factors respondents demonstrate a substantial agreement (even though for the first-order factor the percentage is not meaningful).

Table 3

Means of Agreement/Disagreement Percentages for First-Order Factors

\begin{tabular}{|c|c|c|c|}
\hline & & Disagreement & Agreement \\
\hline \multirow[t]{4}{*}{ Improvement } & $\begin{array}{l}\text { Assessment describe the learning process } \\
\text { (Describe) }\end{array}$ & $44.7 \%$ & $53.9 \%$ \\
\hline & $\begin{array}{l}\text { Assessment improve student learning } \\
\text { (Student learning) }\end{array}$ & $35.3 \%$ & $63.6 \%$ \\
\hline & $\begin{array}{l}\text { Assessment improve the teaching process } \\
\text { (Teaching) }\end{array}$ & $19.9 \%$ & $79.3 \%$ \\
\hline & $\begin{array}{l}\text { Assessment is valid } \\
\text { (Valid) }\end{array}$ & $48.2 \%$ & $50.7 \%$ \\
\hline \multirow[t]{3}{*}{ Irrelevance } & $\begin{array}{l}\text { Assessment is bad } \\
\text { (Bad) }\end{array}$ & $76.1 \%$ & $22.5 \%$ \\
\hline & $\begin{array}{l}\text { Assessment is ignored } \\
\text { (Ignore) }\end{array}$ & $73.6 \%$ & $25.5 \%$ \\
\hline & $\begin{array}{l}\text { Assessment is inaccurate } \\
\text { (Inaccurate) }\end{array}$ & $28.1 \%$ & $70.4 \%$ \\
\hline $\begin{array}{c}\text { School } \\
\text { Accountability }\end{array}$ & $\begin{array}{l}\text { Assessment allows the accountability of } \\
\text { teachers and the school }\end{array}$ & $46.7 \%$ & $52.3 \%$ \\
\hline $\begin{array}{c}\text { Student } \\
\text { Accountability }\end{array}$ & Assessment makes students measurable & $39.2 \%$ & $60.1 \%$ \\
\hline
\end{tabular}

Multivariate analysis of variance (MANOVA) with main effects for the years of experience in school, the educational or training paths on educational assessment, and the school grade was used to test whether teacher trainees' characteristics caused any statistically significant mean difference for the four factors of assessment conceptions model.

The sex variable, as specified above, was not considered due to the relevant gender bias (82.6\% of respondents are women). 
The interaction between teacher trainees' years of experience in school and the four factors of the assessment model (Tab. 4) has a low level of correlation $\left(\mathrm{F}_{1621.59}=1.017\right.$, $p=.040$ Wilks' Lambda $=.758$ ). These values demonstrate a low and not significant difference between the four factors: the years of experience of teacher trainees, in other words, do not influence the conceptions they have of assessment. The participants involved in this study, generally, have not a long experience in school (Tab. 1); however, it is surprising how conceptions of teacher trainees with no experience in school are similar to those of them with 2 or more years of experience at school.

Table 4

Teachers' Years of Experience - COA Model Factors MANOVA Test Multivariate Tests ${ }^{\mathrm{a}}$

\begin{tabular}{clrrr} 
& \multicolumn{1}{c}{ Effect } & Value & \multicolumn{1}{c}{ F } & \multicolumn{1}{c}{ Sig. } \\
\hline \multirow{5}{*}{ Intercept } & Pillai's Trace & .954 & $1621.59^{\mathrm{b}}$ & .000 \\
& Wilks' Lambda & .046 & $1621.59^{\mathrm{b}}$ & .000 \\
& Hotelling's Trace & 20.92 & $1621.59^{\mathrm{b}}$ & .000 \\
& Roy's Largest Root & 20.92 & $1621.59^{\mathrm{b}}$ & .000 \\
\hline \multirow{5}{*}{ Years exp. } & Pillai's Trace & .267 & 1.017 & .440 \\
& Wilks' Lambda & .758 & 1.014 & .446 \\
& Hotelling's Trace & .289 & 1.012 & .452 \\
& Roy's Largest Root & .114 & $1.624^{\mathrm{c}}$ & .040 \\
\hline
\end{tabular}

a. Design: Intercept + Teacher_educ

b. Exact statistic

c. Computed using alpha $=$

The MANOVA tests with teachers' education/training courses on educational assessment (Tab. 5) revealed no statistically significant correlations. In this case the Wilks' Lambda value is very high (.978): past or previous teacher education paths on educational assessment have had no impact on teacher trainees conceptions of assessment. These data, linking to other studies (DeLuca \& Johnson, 2017; DeLuca \& Bellara, 2013; Guskey et al. 2014) confirm how scant is the effect of formal teacher education on teacher trainees, especially in the field of educational assessment.

Table 5

Teachers' Education on Assessment - COA Model Factors MANOVA Test Multivariate Tests ${ }^{\mathrm{a}}$

\begin{tabular}{clrrr} 
& \multicolumn{1}{c}{ Effect } & Value & F & \multicolumn{2}{c}{ Sig. } \\
\hline \multirow{5}{*}{ Intercept } & Pillai's Trace & .976 & $3801^{\mathrm{b}}$ & .000 \\
& Wilks' Lambda & .024 & $3801^{\mathrm{b}}$ & .000 \\
& Hotelling's Trace & 40.33 & $3801^{\mathrm{b}}$ & .000 \\
& Roy's Largest Root & 40.33 & $3801^{\mathrm{b}}$ & .000 \\
\hline \multirow{3}{*}{ Teacher } & Pillai's Trace & .022 & $2.09^{\mathrm{b}}$ & .080 \\
educ. & Wilks' Lambda & .978 & $2.09^{\mathrm{b}}$ & .080 \\
& Hotelling's Trace & .022 & $2.09^{\mathrm{b}}$ & .080 \\
& Roy's Largest Root & .022 & $2.09^{\mathrm{b}}$ & .080 \\
\hline
\end{tabular}

a. Design: Intercept + Teacher_educ

b. Exact statistic

c. Computed using alpha $=$ 
Only the variable of school grade reaches a sufficient correlation with the four conceptions of assessment. All test realized prove a perfect correlation $(p=.000)$.

Table 6

Teachers' School System Grade - COA Model Factors MANOVA Test Multivariate Tests ${ }^{\mathrm{a}}$

\begin{tabular}{clrrr} 
& \multicolumn{1}{c}{ Effect } & Value & F & \multicolumn{2}{c}{ Sig. } \\
\hline \multirow{5}{*}{ Intercept } & .951 & $1488^{\mathrm{b}}$ & .000 \\
& Pillai's Trace & .049 & $1488^{\mathrm{b}}$ & .000 \\
& Wilks' Lambda & 19.45 & $1488^{\mathrm{b}}$ & .000 \\
& Hotelling's Trace & 19.45 & $1488^{\mathrm{b}}$ & .000 \\
& Roy's Largest Root & .141 & 2.83 & .000 \\
\multirow{2}{*}{ School grade } & .863 & 2.88 & .000 \\
& Pillai's Trace & .153 & 2.91 & .000 \\
& Wilks' Lambda & .105 & $8.11^{\mathrm{c}}$ & .000 \\
& Hotelling's Trace & & & \\
& Roy's Largest Root & & &
\end{tabular}

Given this last MANOVA a one-way ANOVA has been performed to explore the four conceptions of assessment from the perspectives of the school grade.

Table 7

Teachers' School Grade - COA Model Factors ANOVA Test

\begin{tabular}{llrrrrr}
\hline & & $\begin{array}{c}\text { Sum of } \\
\text { Squares }\end{array}$ & Df & Mean Square & F & Sig. \\
\hline \multirow{3}{*}{ Improvement } & Between Groups & 5.347 & 4 & 1.337 & 4.966 & .001 \\
& Within Groups & 83.174 & 309 & .269 & & \\
& Total & 88.522 & 313 & & & \\
\hline \multirow{3}{*}{ Irrelevance } & Between Groups & .419 & 4 & .105 & .275 & .894 \\
& Within Groups & 117.755 & 309 & .381 & & \\
\hline \multirow{3}{*}{ School_Accountability } & Total & 118.174 & 313 & & & \\
& Between Groups & 1.950 & 4 & .488 & .552 & .698 \\
& Total Groups & 272.930 & 309 & .883 & & \\
\hline \multirow{2}{*}{ Student_Accountabilit } & Between Groups & 474.881 & 313 & & & \\
y & Within Groups & 174.782 & 4 & 1.006 & 1.778 & .133 \\
& Total & 178.808 & 309 & .566 & & \\
\hline
\end{tabular}

There was non-significant difference for the scores on data and non-significant correlations. Only Improvement factor appears to be somewhat significantly correlated with the school grade $(\mathrm{F}=4.966, p<0.5)$. The $\mathrm{F}$ values for Irrelevance and School Accountability conceptions are not relevant in terms of school grade. A difference can by highlighted for Student Accountability, however, the $p$ value shows a significant difference between groups $(p>0.5)$.

The one-way ANOVA indicates not so consistent differences in terms of teacher trainees school grade. These results suggest that participants involved in this study have similar conceptions of assessment irrespective of the different school grade (e.g. middle or high school). Moreover, Improvement is the conception more relevant compared to the other three conceptions of assessment that correlates with the school grade variable: a possible explanation is that teacher trainees have a low level of knowledge for the more technical 
aspects of assessment (e.g. those related to School Assessment): they tend to not consider assessment in terms of the national educational system and to focus their attention only on the teaching-learning process within the classroom. Further research is needed in order to understand if, and how, teacher trainees' conceptions of assessment can be different in relation to the school grade.

The insignificant differences between variables of teacher trainees' experience, training paths on educational assessment, and school grade in most of the items indicate how these aspects do not impact conceptions of assessment. These results indicate that teacher trainees' conceptions are flattened and no differentiated.

\section{DISCUSSION}

This study sheds light on the Italian teacher trainees' conceptions of assessment. The picture that comes out from gathered data, however, is not particularly encouraging.

The four conceptions of assessment indicated by the model of Brown in this study were indistinct. This is the first main relevant difference showed by the results: while research literature in this filed has addressed how teachers' conceptions are hierarchical, complex, multidimensional, teacher trainees involved in the study demonstrated to have flattened and undifferentiated conceptions of assessment. More specifically there is no difference between teachers who have attended a course on educational assessment and those who have never attended one. Teacher education and/or teacher training (as showed by MANOVA tests in this study) do not affect what teacher trainees think about assessment. This is a relevant aspect to be considered in terms of educational policy and educational practice for teachers: it is likely that teacher education has had no impact on teachers' conceptions of assessment: teacher education or teacher training paths do not modify their conceptions. While sharing practices and modelling expert teachers can have a stronger effect on teachers' conceptions than teacher education or teacher professional development paths (Kahm 2000; Pajares, 1992), these formal paths sometimes are not really meaningful, useful, and transferable in the context of a classroom. Teachers generally tend to consider assessment as something that is functional to improve teaching and learning processes. The idea that assessment is something related only to the context of the classroom is evident also in the representation of assessment as a descriptive practice and with a qualitative methodological design. Teacher trainees do not consider the technical aspects related to assessment and to assessment literacy (e.g. how to gather valid and robust data, how to assign marks and grades, how to use a test). As Daniels et al. (2014) pointed teacher trainees, generally, «have not yet begun to view assessment as a broad and multifaceted concept» (153). They tend to focus on potential purposes and functions of assessment in terms of immediate practice in the classroom. In this vein, it is not surprising that they perceive the other "assessment forms" (e.g., school and student assessment) as something that is far from the idea of teacher and the model of teaching practice and that, for this reason, appears more challenging for them in terms of professional practice.

Secondly, School Accountability and Student Accountability dimensions are not in line with Brown's previous results. As pointed by other studies (Barnes et al., 2015; Daniels 
et al., 2014) generally, Improvement factors and sub-factors were rated most highly and negative factors lowest. Present results confirm this, in part, only for the Improvement factor. Teacher trainees consider assessment as a way to certify their work and school performances but this idea is more perceived in terms of mandatory practice: for them the real sense of assessment practice pertains to students' level of achievement. A gap between improvement and accountability is evident: if, on the one hand, assessment is perceived as a chance to support and improve teaching and learning processes, on the other one, it is well-rooted the idea that assessment is only a way to measure and account students' performances and their levels of achievement. This difference emerges also with the years of experience variable. A possible explanation of this polarization is that because teacher trainees are still students and tend to experience assessment in more simplistic way.

The present results confirm what has been proven by previous studies: age, sex, teacher education, and years of service of teachers do not affect the Brown's model of COA_III. Even though Brown's studies have not founded differences in relation to the socioeconomic background of schools, the findings of this study suggest a correlation between the four main factors and the school grades. Further research, however, in this field is needed to understand what conceptions teachers (and teacher trainees) have of assessment and how these conceptions impact the alignment of assessment practices within a nations school system.

\section{LIMITATIONS}

One limitation pertains to this study. The sample is not representative of all the Italian school system. Variables such as the school grade are limited to the use of a convenience sample. However, despite its limitations this study allows to shed light on the impact of teacher conceptions in the assessment domain and to carefully consider how to invest in teacher education policies and practices: it is a necessary step to change teachers' assessment culture and practices in the Italian school system.

\section{CONCLUSIONS}

What teachers think of assessment has been often considered as a neglected aspect in teacher professionalism. The findings of this study, in line with previous research literature, confirm how teachers' conceptions exert a crucial role, especially when teachers are in transition with institutional changes. Further research is urgent: «teachers are a key factor in turning assessment information and processes into improved learning. Thus it is important to understand what teachers think about assessment and how to make use of it» (Brown et al., 2009: 348). Assessment, as teaching practice, is a complex research object: different variables and elements have to be considered. However, scant are studies aimed to help teachers to understand criticalities in their job and to improve their practice (Ponte, 2002; Wallace, 1998).

Teachers' conceptions can influence teaching practice and teachers' reactions to institutional and policy reforms: a research focus on teachers' conceptions of assessment is relevant to lead the diffusion of an assessment culture within the Italian school system. 
Teacher education paths should be based not only on technical-practical assessment aspects (e.g., knowledge, skills, resources, and tools) but should be focused also on how teachers conceive assessment in older to help them «become aware of their conception of assessment and how these might influence assessment decision they make as practising teachers» (Daniels et al., 2014: 155)

This study confirms that there is an urgent need to invest in teachers' judgment, training it up through educational and professional programs focusing sharply on assessment and through internal and external moderation networks.

As Remesal pointed conceptions of assessment «provide a convenient reference for the critical review of teacher education programs. These results must be taken into account, if we aim at the development of teachers' assessment competencies towards the implementation of assessment practices, likely to improve educational processes in its full extent and complexity» (2011: 480).

\section{REFERENCES}

Bandura, A. (1989). Human agency in social cognitive theory. American Psychologist, $44,1175-1184$.

Barnes, N., Fives, H., \& Dacey, C. M. (2015). Teachers' beliefs about assessment. In H., Fives and M., Gregoire Gill (Eds.). International handbook of research on teacher beliefs (pp. 284-300). New York, NY: Routledge.

Betoret, F. D., \& Artiga, A. G. (2004). Trainee teachers' conceptions of teaching and learning, classroom layout and exam design. Educational Studies, 30, 355-372. doi.org/10.1080/0305569042000310309.

Brown, G. T. L. (2004). Teachers' conceptions of assessment: Implications for policy and professional development. Assessment in Education, 11, 301-318. doi:10.1080/0969594042000304609.

Brown, G. T. L. (2006). Integrating teachers' conceptions: assessment, teaching, learning, curriculum and efficacy. In M.B. Klein, New teaching and teacher issues (pp. 1-49). New York: Nova Science Publishers.

Brown, G. T. L. (2009). Teachers' self-reported assessment practices and conceptions: Using structural equation modelling to examine measurement and structural models. In T. Teo, \& M. S. Khine (Eds.), Structural equation modelling in educational research: Concepts and applications (pp. 243-266). Rotterdam, NL: Sense Publishers.

Brown G. T. L., Gebril A., \& Michaelides, M. P. (2019). Teachers' conceptions of assessment: A global phenomenon or a global localism. Frontiers Education, 16, 1-13. doi: 10.3389/feduc.2019.00016

Brown, G. T. L., Kennedy, K. J., Fok, P. K., Chan, J. K. S., \& Yu, W. M. (2009). Assessment for student improvement: Understanding Hong Kong teachers' conception and practices of assessment. Assessment in Education: Principles, Policy \& Practice, 16, 347-363. doi.org/10.1080/09695940903319737. 
Brown, G. T. L., Lake, R., \& Matters, G. (2011). Queensland teachers' conceptions of assessment: The impact of policy priorities on teacher attitudes. Teaching and Teacher Education, 27, 210-220. doi:10.1016/j. tate.2010.08.003.

Calveric, S. B. (2010). Elementary teachers' assessment beliefs and practices (Unpublished doctoral dissertation). Virginia Commonwealth University, Virginia.

Calderhead, J. (1996). Teachers: Beliefs and knowledge. In D. Berliner, \& R. Calfee (Eds.), Handbook of educational psychology (pp. 709-725). New York, NY: Macmillan.

Cheung, D. (2000). Measuring teachers' meta-orientations to curriculum: Application of hierarchical confirmatory analysis. Journal of Experimental Education, 68, 149-165. doi.org/10.1080/00220970009598500.

Cheung, D., \& Wong, H.W. (2002). Measuring teacher beliefs about alternative curriculum design, The Curriculum Journal, 13, 225-248. doi.org/10.1080/09585170210136868.

Cochran-Smith, M. (2016). Teaching and teacher education: Absence and presence in AERA presidential addresses. Educational Researcher, 45, 92-99. doi.org/10.3102/0013189X16639040.

Dahlin, B., Watkins, D. A., \& Ekholm, M. (2001). The role of assessment in student learning: the view of Hong Kong and Swedish lecturers. In D. A. Watkins, \& J. B. Biggs (Eds.), Teaching the Chines learner: Psychological and pedagogical perspective (pp. 47-74). Hong Kong: University of Hong Kong, Comparative Education Research Centre.

Daniels, L. M., Poth, C., Papile, C., \& Hutchison, M. (2014). Validating the conceptions of assessment-iii scale in Canadian preservice teachers. Educational Assessment, 2, 139158. doi: 10.1080/10627197.2014.903654.

Darling-Hammond, L., \& Bransford, J. (2005). Preparing teachers for a changing world. New York: Jossey Press.

DeLuca, C., \& Bellara, A. (2013). The current state of assessment education: Aligning policy, standards, and teacher education curriculum, J of Teacher Edu, 4, 356-372.

DeLuca, C., \& Johnson, S. (2017). Developing assessment capable teachers in this age of accountability. Assessment in Education: Principles, Policy \& Practice, 1, 107-126.

Dwyer, C.A., \& Villegas, A.M. (1993). Guiding conceptions and assessment principles for the Praxis Series: Professional assessments for beginning teachers. (Research Report, 93-17). Princeton, NJ: Educational Testing Service.

Eisner, E. W., \& Vallance, E. (1974). Conflicting conceptions of curriculum. Berkeley, CA: McCutchan.

Entwistle, N. (1997). Contrasting perspectives on learning. In F. Marton, D. Hounsell, \& N. Entwistle (Eds.). The experience of learning: Implications for teaching and studying in higher education (pp. 3-22). Edinburgh: Scottish Academic Press. 
Fives, H., \& Buehl, M. M. (2012). Spring cleaning for the "messy" construct of teachers' beliefs: What are they? Which have been examined? What can they tell us? In K. R. Harris, S. Graham, \& T. Urdan (Eds.). APA educational psychology handbook: Individual differences and cultural and contextual factors, vol. 2. (pp. 471-499). Washington, DC: APA.

Gebril, A., \& Eid, M. (2017). Test preparation beliefs and practices: A teacher's perspective. Language Assessment, 14, 360-379. doi: 10.1080/15434303.2017.1353607.

Gow, L., \& Kember, D. (1993). Conceptions of teaching and their relationship to student learning. British Journal of Educational Psychology, 63, 20-33. doi:10.1111/j.2044-8279.1993.tb01039.x.

Graham, P. (2005). Classroom-based assessment: Changing knowledge and practice through pre-service teacher education. Teaching and Teacher Education, 21, 607-621. doi:10.1016/j.tate.2005.05.001.

Guskey, T. R., \& Passaro, P. D. (1994). Teacher efficacy, A study of construct dimensions. American Educational Research Journal, 31, 20-33. doi.org/10.3102/00028312031003627.

Guskey T. R., Roy, P., \& von Frank, V. (2014). Reaching the highest standard in professional learning: Data. Thousand Oaks, CA: Corwin Press \& Learning.

Kember, D. (1997). A reconceptualisation of the research in university academics' conceptions of teaching. Learning and Instruction, 7, 255-275. doi.org/10.1016/S09594752(96)00028-X

Kennedy, K. J. (2016). Exploring the influence of culture on assessment: The case of teachers' conceptions of assessment in confucian-heritage cultures. In G. T. L., Brown \& L. R. Harris (Eds.), Handbook of human and social conditions in assessment, (pp. 404-419). New York: Routledge.

Klenowski, Val. (Ed.). (2016). International teacher judgement practices. New York, NY: Routledge, Abingdon, Oxon.

Li, W.S., \& Hui, S.K.F. (2007). Conceptions of assessment of mainland China college lectures: A technical paper analyzing the Chinese version of COA-III. The Asia PacificEducation Researcher, 16, 185-198.

Marton, F. (1981). Phenomenography-describing conceptions of the world around us, Instructional Science, 10, 177-200. doi:10.1007/BF00132516.

Marton, F., \& Saljo, R. (1976). On qualitative differences in learning. I - outcome and process. British J of Edu Psyc, 42, 4-11. doi.org/10.1111/j.2044-8279.1976.tb02980.x.

Pajares, M. F. (1992). Teachers' beliefs and educational research: Cleaning up a messy construct, Review of Edu Research, 62, 307-332. doi.org/10.3102/00346543062003307. 
Ponte, P. (2002). How teachers become action researchers and how teacher educators become their facilitators. Educational Action Research, 10, 399-423. doi.org/10.1080/09650790200200193.

Pratt, D.D. (1992). Conceptions of teaching. Adult Education Quarterly, 42, 203-220. doi.org/10.1177/074171369204200401.

Remesal, A. (2011). Primary and secondary teachers' conceptions of assessment: A qualitative study. Teaching and Teacher Education, 27, 472-482. doi: 10.1016/j.tate.2010.09.017.

Samuelowicz, K., \& Bain, J. D. (1992). Conceptions of teaching held by academic teachers. Higher Education, 24, 93-111. doi:10.1007/BF00138620.

Scheerens, J. (1992). Effective schooling: Research, theory and practice. London/New York: Cassell.

Schommer, M. (1990). The effects of beliefs about the nature of knowledge on comprehension. Journal of Educational Psychology, 82, 498-504. doi.org/10.1037/0022-0663.82.3.498.

Schraw, G., Bendixen, L. D., \& Dunkle, M. E. (2002). Development and validation of the epistemic belief inventory (EBI). In B. K. Hofer, \& P. R. Pintrich (Eds.), Personal epistemology: The psychology of beliefs about knowledge and knowing (pp. 261-276). Mahwah, NJ: Lawrence Erlbaum.

Teddie, C., \& Reynolds, D. (2000). The international handbook of school effectiveness research. London/New-York: Falmer Press.

Townsend, T., \& Bates, R. (2007). Handbook of teacher education. Dordrecht: Springer.

Trigwell, K., \& Prosser, M. (1997). Towards an understanding of individual acts of teaching and learning. Higher Education Research and Development, 16, 241-252. doi.org/10.1080/0729436970160210.

Tschannen-Moran, M., Woolfolk Hoy, A., \& Hoy, W. K. (1998). Teacher efficacy: Its meaning and measure. Review of Educational Research, 68, 202-248. doi.org/10.3102/00346543068002202.

Vandeya, S., \& Killen, R. (2007). Educators' conceptions and practices of classroom assessment in post-apartheid South Africa. South Africa J of Education, 27, 101-115.

Vardar, E. (2010). Sixth, seventh, and eighth grade teachers' conception of assessment (Unpublished master thesis). Middle East Technical University, Ankara.

Wallace, M. J. (1998). Action research for language teachers. New York, NY: Cambridge University Press. 
Wood, P., \& Kardash, C. (2002). Critical elements in the design and analysis of studies of epistemology. In B. K. Hofer \& P. R. Pintrich (Eds.), Personal epistemology: The psychology of beliefs about knowledge (pp. 231-261). Mahwah, NJ: Lawrence Erlbaum. 